\title{
富山県におけるメニエール病患者の疫学調査
}

\author{
水越 鉄理・将積日出夫・浅井 正嗣 \\ 大井 秀哉・渡辺 行雄・大橋 直樹
}

\section{An Epidemiological Study of Meniere's Disease in Toyama Prefecture}

\author{
Kanemasa Mizukoshi, Hideo Shojaku, Masatsugu Asai, \\ Hideya Ohi, Yukio Watanabe and Naoki Ohashi
}

(Toyama Medical and Pharmaceutical University)

Three hundred and twenty-three patients with Meniere's disease were registered to have an intractable disease from 779 members or clinics of the Toyama Medical Association in Toyama Prefecture in 1974 and 1979. Of the 1, 044 patients who had visited the Neuro-Otological Clinic of the Toyama Medical and Pharmaceutical University Hospital during the three years from October 1979 to December 1982, 102 patients were diagnosed to have Meniere's disease including atypical cases. An epidemiological study of these patients were made and the following characteristic epidemiological features were obtained.

1) The incidence of Meniere's disease in Toyama Prefecture was estimated to be 14.7 per 100,000 population on the basis of the registration of this intractable disease made by the members of the Toyama Medical Association.

2 ) Sex-ratio: The incidence was higher in males than females in Toyama Prefecture.

3 ) Age-distribution: The age distribution of the 102 patients with Meniere's disease peaks at the age group of 40-49 years for males and females.

4 ) There was an increasing number of patiebts in the cities of Toyama Prefecture compared with the countryside. This tendancy was seen in the patients collected by the Toyama Medical Association.

5 ) Season of onset: There was an apparent high incidence of initial vertiginous attack in March and in October. This tendency was seen in patients from Toyama Medical and Pharmacutical University Hospital.

6 ) The incidence of bilateral Meniere's disease: Of the 102 patients with Meniere's disease (including atypical cases), 9 were bilateral(8.9\%).

\section{は じめに}

メニエール病の疫学的調査は昭和 49 年厚生省の調査研究班が結成され全国的調查活動が数次に行 われているが, 特定地区での疫学調査は長崎県五島地区, 神奈川県相模原市の調査のみで, 極めて 少ない現状である（水越, 猪1977, 水越1982, 渡辺, 他1976, 1980, 徳増, 他1982).

今回，私共は人口約 110 万人の富山県に打けるメニエール病患者の疫学的調査について，昭和 49 年, 昭和 54 年の県医師会による特定疾患患者の実態調査と昭和 54 年 10 月開院以来の富山医科薬科大 
学附属病院神経耳科外来患者1044例の疫学的調查をもとに, 若干の検討を加えたので, その一部を 報告する.

\section{調查方法とその対象}

A）県医師会による特定疾患実態調査

富山県厚生部においては特定疾患の実態調査 について昭和 49 年以来, 県医師会を通じて每年 10〜13特定疾患の調查が行なわれており，メ二 エール病についても昭和 49 年, 昭和54年の 2 回，調查が行なわれている. 調査機関は県下の 国公立病院, 個人病院医院 700 機関以上で, 回 収率も常に $70 \%$ 以上を占めて拈り, 昭和 56 年度 では779機関で回収568機関（回収率72.9\%）を 示していた。

今回の調査は昭和 49 年, 54 年の特定疾患実態 調査のらち, メニエール病 323 例について回収 時の年齢, 性別, 発生地区の地理的分布, 有病 率などについて検討した。
B）富山医科薬科大学附属病院のメニエール病 患者の疫学的実態調査

富山医薬大附属病院は昭和54年10月15日開院 し，県下の中心に位置しており，医療機関の中 心的役割を果し，全県下の患者が受診してい る.したがって, 特定疾患であるメニエール病 の受診率も高く，その10\%近くが受診している ものと推定される. 今回, 私共は開院以来, 私 共の神経耳科外来に来院した患者1044例中， メ ニエール病確実例55例, 疑い例47例について, 発症年齢, 性別, 発生地区, 職業分布, 発生月, 患側, 経過年数などについて疫学的調査を行な った。

\section{調 查 結 果}

\section{A）県医師会による実態調査}

1) 登録時の患者年齢と性別: 特定疾患入二エ 一ル病として登録された患者 323 例について年 齢分布を性別に分けてみると, 図 1 亿示寸如 く, 男性では50歳代, 女性では40歳代にピーク をもつ一峰性分布で, 压倒的に女性に多発して いる.

2) 登録時の患者住所分布と有病率 : 人口10万 人に対する有病率について， 2 年の 323 例を 2 分し, 人口 $1,098,112$ 人（昭和 54 年）に対して

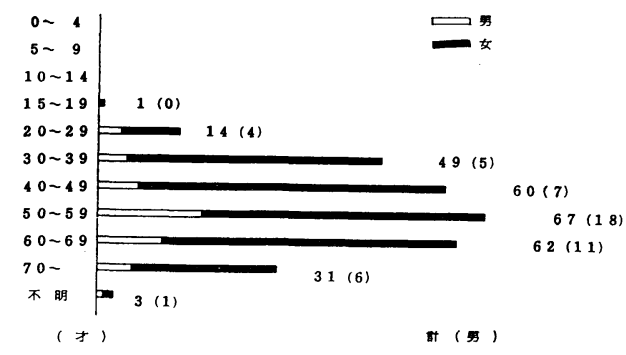

図 1 富山県医師会の実態調査によるメニエール 病患者の年令別・性別分布
323/2とすると，14.7と推定される.

2 年間の 323 例の県下の地理的分布をみると, 図 2 亿示す如く, 富山市, 水見市, 新湊市が高 く, 八尾町, 婦中町を加之た富山近郊に多く, 高岡市などの県西部地区, 田園, 漁村地区に小 ない傾向がみられた。

B) 富山医薬大神経耳科の疫学的実態調査

1) 性別・年齢分布：メニエール病確実例では 男女とも40歳代にピークをもつ一峰性分布を示 し，疑い例では男女とも30歳代にピークをもつ 一峰性分布を示した. 男女比では確実例（男女 比: 23/32), 疑い例（男女比: 19/28）ともに 女性が多い傾向がみられた（図 3 ).

2) 発病時の住所（地理的分布）: メニエール 病患者の住所は患者来院の動向から圧倒的に富 山市が多く, 県医師会の患者分布に比して偏っ た傾向を示しており, 病院全体の患者動向から の考察が必要とみられたが，都市部に多い傾向 がみられた。

3 ) 職業的分類の分布：職業分布を男女に分け 


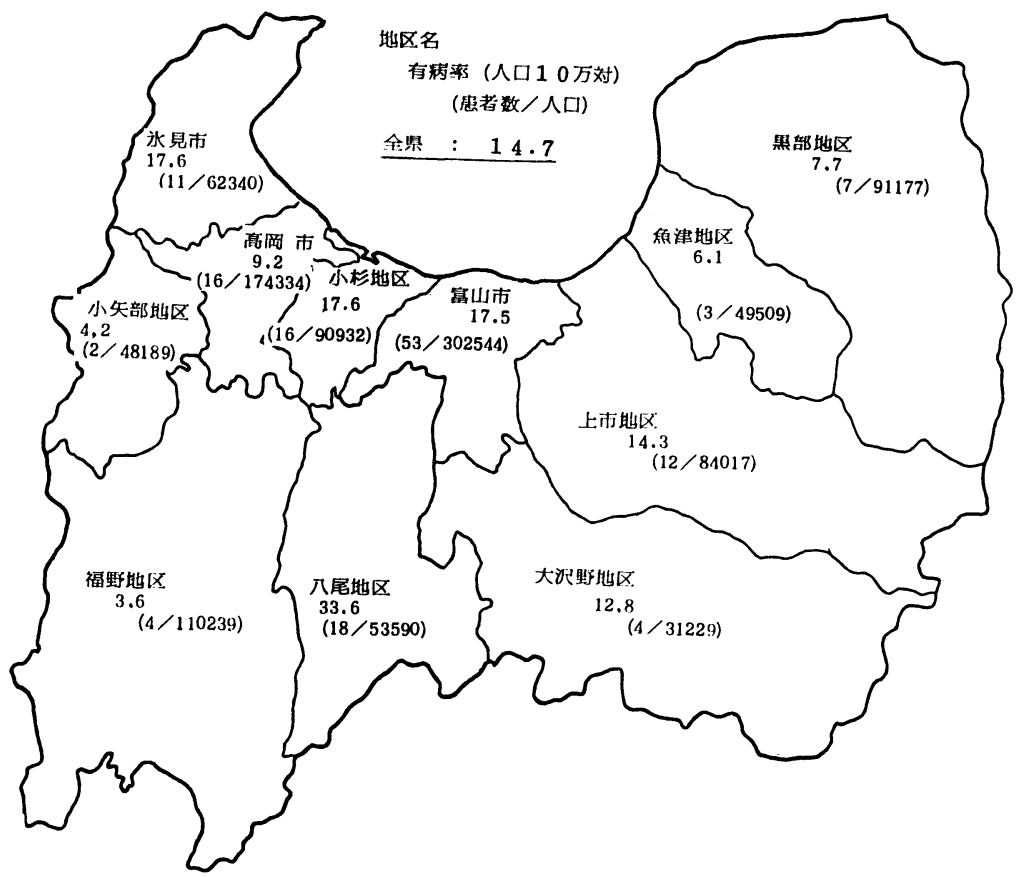

図 2 富山県医師会の実態調査によるメニェール病の地理的分布

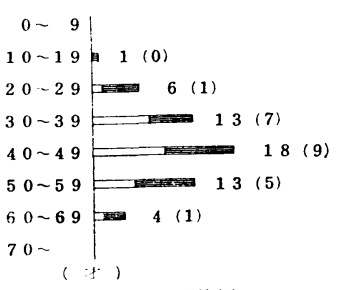

碓斩例

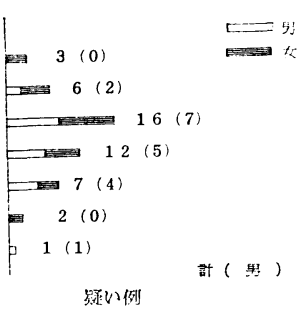

図 3 富山医薬大の神経耳科外来のメニエール病 の確実例・疑い例の発生年令別・性別分布

て, 前回厚生省メニエール病調查研究班の疫学 調査結果と比較してみると，表 1 の如く，男性 では管理職, 事務職, 運輸・通信職に多く, 女 性では農林漁業職に多い傾向がみられた。

4）発症の季節：各月毎に発病例を集計してみ ると，表 2 の如く，3 月と10月に多発し， 2 月 6 月，11月に低い傾向がみられた。

5 ) 患側について : メニエール病の患側につい ては随伴する聴力障害, 耳鳴, 耳閉塞感, 前庭 反応の低下などにより推定されるが，確実例， 疑い例を含めて患側を推定すると，表 3 の 如 く, 両側例は 9 例 $(8.82 \%)$ で, 左右差は殆ん
表 1 富山医薬大神経耳科外来のメニエール病 患者の職業分布（確実例・疑い例の集計）

\begin{tabular}{|c|c|c|}
\hline 職 & $\begin{array}{l}x=エ ー ル \text { 病 } \\
\text { 男 } \% \text { 全国\% }\end{array}$ & $\begin{array}{l}x=エ ー ル \text { 病 } \\
\text { 女 } \% \text { 全国 } \%\end{array}$ \\
\hline 専門技術 & $\begin{array}{lll}3 & (7.1) & 13.2\end{array}$ & 10.4 \\
\hline 管 理 & $6(14.2) \quad 6.6$ & 1.9 \\
\hline 事 務 & $6(14.2) \quad 12.4$ & $2(3.0) \quad 8.0$ \\
\hline 販 売 & $2(4.8) \quad 5.4$ & $2(3.3) \quad 4.2$ \\
\hline 農林・漁 & $2(4.8) \quad 1.5$ & $5(8.3) \quad 4.2$ \\
\hline 採 鉱 & 0.4 & 0 \\
\hline 運輸通信 & $4(9.5) \quad 5.0$ & $\begin{array}{ll}0 & 0.4\end{array}$ \\
\hline 生産労働 & $6(14.2) \quad 15.8$ & $\begin{array}{lll}3(5.0) & 9.2\end{array}$ \\
\hline 保安サービス & $2(4.8) \quad 2.7$ & $5(8.3)$ \\
\hline 分類不能 & 2.3 & 2.7 \\
\hline 会社員 & $8(19.0) 27.3$ & $\begin{array}{lll}2(3.3) & 1.9\end{array}$ \\
\hline 主 婦 & & $30(50.0) \quad 49.0$ \\
\hline 学 生 & $1(2.3) \quad 2.7$ & $2(3.3) \quad 3.1$ \\
\hline 無 職 & $5(11.9) \quad 0.8$ & $7(11.7) \quad 2.3$ \\
\hline (計) & $42(100)(100)$ & $60(100)(100)$ \\
\hline
\end{tabular}

どみられなかった（左/右 $=45 / 48 ）$.

$6)$ 経過年数について: 来院時のメニエール病 経過年数を発症時より推定してみると，表 4 の 
如く，1 月月以内も多いが，10年以上の長期症 例も確実例で 7 例, 疑い例で 4 例にみられ, 最 長期間例では 24 年の例がみられ, 平均 4 年 7 力 月であった。

表 2 富山医薬大神経耳科外来のメニエール病 患者の発生季節分布 (102例)

\begin{tabular}{c|r|r|c}
\hline 発症月 & 例数 & $(\%)$ & 全国調査 $(\%)$ \\
\hline 1 & 5 & $(4.9)$ & 6.2 \\
2 & 2 & $(1.9)$ & 5.6 \\
$(3)$ & 10 & $(9.8)$ & 7.9 \\
4 & 8 & $(7.8)$ & 6.9 \\
5 & 9 & $(8.8)$ & 8.7 \\
6 & 4 & $(3.9)$ & 9.6 \\
7 & 6 & $(5.9)$ & 6.7 \\
8 & 7 & $(6.9)$ & 7.9 \\
9 & 8 & $(7.8)$ & 5.6 \\
(10) & 13 & $(12.7)$ & 7.7 \\
11 & 4 & $(3.9)$ & 5.6 \\
12 & 7 & $(6.9)$ & 7.3 \\
不明 & 19 & $(18.6)$ & 14.5 \\
\hline 計 & 102 & $(100)$ & $120(100 \%)$ \\
\hline
\end{tabular}

考

メニエール病の疫学調査は本邦では厚生省の 特定疾患調查研究班が結成されて以来，全国的 規模により数次にわたり調査活動が行なわれ， 個体因子と環境因子が怙互に関与しているもの と考えられている（渡辺，他1976, 中江, 他19 80, 水越, 他 1977,1982$)$. これらの疫学的特 徵を従来の内外の調査報告（内藤1973, Watanabe, 1980, Watanabe et al 1981, Stahle et al 1978. Morrison 1975, Mizukoshi, et al 1979）も含めて, 今回私共の調査結果について 比較検討してみる.

1) 性別: 従来私どもの行なった全国調査 (520 例）では男性259例, 女性261例でほぼ同数の分 布を示していたが (水越, 他1977), Watanabe （1981）によれば，第 2 次大戦後（1948～1967） は比較的男性に頻発したメニエール病が除々に 女性にも増加し, 最近では女性優位に移行して
表 3 富山医薬大神経耳科外来のメニェール病 患者の患側 (102例)

\begin{tabular}{|c|c|c|c|c|c|}
\hline 患側 & \multicolumn{2}{|c|}{ 確 実 例 } & $\begin{array}{l}\text { 疑 } \\
\text { 男 }\end{array}$ & $\begin{array}{l}\text { 例 } \\
\text { 女 }\end{array}$ & 部 $(\%)$ \\
\hline 右側 & 7 & 15 & 10 & 16 & $48(47.0)$ \\
\hline 左側 & 13 & 13 & 10 & 9 & $45(44.1)$ \\
\hline 両側 & 2 & 5 & 0 & 2 & $9 \quad(8.9)$ \\
\hline & 22 & 33 & 20 & 27 & $102(100)$ \\
\hline
\end{tabular}

表 4 富山医薬大神経耳科のメニエール病患者 の経過年数 (102例)

\begin{tabular}{|c|c|c|c|c|}
\hline & & 例 & 疑 & 例 \\
\hline 経過年数 & 男 & 女 & 男 & 女 \\
\hline ～30日 & 5 & 6 & 6 & 7 \\
\hline 1 月～ 2 月 & 2 & 1 & 3 & 2 \\
\hline 3 月～5月 & 1 & 3 & 1 & 1 \\
\hline 6 月～12月 & 5 & 6 & 2 & 1 \\
\hline 1 年 2 年 & 3 & 7 & 4 & 5 \\
\hline 3 年 4 年. & 0 & 5 & 0 & 6 \\
\hline 5 年～ 9 年 & 3 & 1 & 3 & 2 \\
\hline 10 年以上 & 3 & 4 & 1 & 3 \\
\hline
\end{tabular}

(平均: 4 年 7 月)

按

いる.

この点, 今回の富山県の調査では県医師会の 実態調査でも大学病院の調査でも女性が圧倒的 に多く発生していた。このように，近時女性患 者の増加現象は妊娠・出産などの内分泌・代謝 の影響も否定できないが (Watanabe 1981), 女性の社会への進出によるストレスの増加もそ の一因かと推察される.この点, 富山県では女 性の就業率は高く，主婦のパートタイマーが多 いのも一因と考光られるが，今後，さらに詳し く追跡したい。また，諸外国の報告でも男女ほ ぼ同数が多いが (Morrison 1975)，女性が多 い報告もみられる (Stahle et al 1978).

2) 初発年齢：メニエール病の初発年齢は全国 調査580例で男女ともに40歳代，520例で男40歳 代, 女30歳代にピークをもつ一峰性分布であっ た（渡辺, 他1976, 水越, 他1977)。この点, 
私共の調査（医薬大）では確実例で男女とも40 歳代, 疑い例では30歳代にピークをもつ一峰性 分布で, 全国調查とほぼ一致していた。ささら に, 今回の医師会の調査をみると, 受診時の年 龄であるので, 罹患年数分高齢化して扣り，男 50 歳代, 女40歳代をピークとする一峰性分布を 示していた。

3) 地理的分布と有病率: 本邦で行なわれた全 国調査では何れも北に低く, 南西に高い傾向が みられるが（内藤1973, 渡辺, 他1976, 水越, 他1977), 県単位の小地区の調査はなく, 長崎の 五島地区のめまい多発の追跡（渡辺, 他1981), 相模原市のメニエール病の疾患統計 (徳増, 他 1982）のみである. 今回の私共の県医師会の実 態調査では医療機関として大病院から診療所ま で内科, 外科, 整形外科, 神経内科, 耳鼻科と 全診療科を対象としており，700医療機関にお よび，その回収率も極めて高い。これは富山県 ではメニエール病に対しても一部医療費の交付 がなされており，多少診断基準の解釈に抎大が みられるが，厚生省の特定疾患の診断基準を交 付して調查したものである, 今回の富山県のメ ニェール病有病率 (人口 10 万人対 14.7 ) は相模 原市の推定 16.764 , 特定疾患調査研究班の 1 日 調査16.1, 1 週間調査3.5 (中江, 他1980) に比 較的似通った数值と又られた. しかし, 英国の 10万人対 100 有病率 (Harrison, 1968), Sweden 910 万人対 46 の有病率に比してやや低い傾
向を示していた。 また，地理的分布も比較的県 東部の都市部に多い傾向がみられており, 内藤 (1973) の Menierization is civilization の概 念は合致しているものと推察された.

4 ) 職業別分布: 調查研究班の全国調査 (520 例）では専門技術職に多く, 農林漁業, 技能単純 労働者に少ない傾向がみられたが（水越, 他 1977), 今回の私共の調查でも管理職, 主婦, 保 安サービス業に多い傾向がみられ，ストレスに よる環境要因も無視できない。

5 ）季節の集積性：前回の調査研究班の全国調 查 (520例) では季節集積性はなかったが，安田 (1972) によると，メニエール病の 発病は冬期 最低気温が $4{ }^{\circ} \mathrm{C}$ 以下になると起り易く， 1 年間 では気圧の変動が激しい時, 起り易いと述べて いる(安田1978).この点, 今回の私共の調査で は 3 月と 10 月に多発しているが，症例数も少な く今後の追跡に期待したい.

6 ）両側性罹患について: 先に, 私共は調査研 究班の両側性 $x=エ ー ル$ 病症例48例 (520例中, 9.4\%)について, 疫学的にも検討しているが, 一般に，女性に多く，40歳代に多発し，家族発 生が高率で, 既婚者に多く, 低血圧, 糖尿病の 合併が多かった（水越，他1980). 今回も女性 に多かったが，症例数も少なく今後の追跡に待 ちたい. 両側化の頻度も10\%前後という一般的 な值を示していた。

\section{ま と め}

富山県に打けるメニエール病患者について, 県医師会の厚生省特定疾患の実態調查 323 例（昭和 49 年，昭和54年）と富山医薬大神経耳科外来102例（昭和54年10月〜昭和57年12月）を中心に，疫学的 検討を加え, 次の疫学的特徵が得られた.

1) 富山県のメニエール病は女性に多く，40歳代にピークをもつ一峰性分布を示した.

2 ) 地理的分布は比較的県東部の都市部に多発し，その有病率は人口 10 万人対 14.7 と推定された. 3 ) 職業別では比較的管理職, 運輸, 通信職, 主婦に多く, 季節的には 3 月, 10 月に多発し, 2 月, 6 月，11月に低い傾向を示した.

稿を終るに当り, 今回の調查活動にご協力下さり, 貴重なアンケート資料, 調査結果を提供して下さった富山 県医師会 (会長: 本田幸男先生), 富!県特定疾患対策協議会ならびに富山県公衆衛生課の方々に心から厚くお 礼わしはげます。 
本研究は厚生省特定疾患前庭機能異常調査研究費による成果である.

\section{参 考 文 献}

1) 水越鉄理, 诣 初男: メ二エール病没学調査研究 ( 3 年間のまとめ). 耳鼻臨休 70 ：増 5 ；1687$1690,1977$.

2 ) 水越鉄理 : メニエール病調査研究班の疫学的研究 のまとめ (1977〜1979). 耳鼻臨休 75 ：増 3；11 45-1149, 1982.

3 ）渡辺 勈, 水越鉄理, 中江公裕, 大久保仁: 全国 国17施設におけるメニエール病確実例の疫学調査 成績. 耳鼻臨床 69: 増 4；1176-1782，1976.

4) 渡辺 勈, 大久保仁, 小松崎篤, 江上徹也, 中島 成人, 藤原久郎, 中村信勝 : 上五島におけるめま い検診報告：メ二エール病調査研究班昭和 54 年度: 報告書，45-47，1980.

5 ）徳増厚二, 田代直樹, 五島一吉, 斉藤 彰, 川野 六郎，広瀬陽子，末王 敏 : 相模原市（神奈川 県）のメニェール病疾患統計.耳鼻臨床 75 : 増 3 ; 1165-1173, 1982.

6 ）中江公裕，新田裕史，服部芳郎，前田和甫，渡辺 勈, 水越鉄理, 小松崎篤: メニエール病の有病率 耳鼻臨床 73 ；増 $2 ； 1023-1029 ， 1980$.

7) 内藤 儶: メニエール病. 耳鼻臨床 60 : 增 1 : 1-48, 1973.

8) Watanabe I.: Meniere's Disease. With special emphasis on epideminology diagnosis and prognosis. ORL 42: 20-25, 1980.

9) Watanabe I. : Meniere's disease in males and females. Acta Otolaryngol. 91: 511-514, 1981.

10) Watanabe I. Mizukoshi K. Nakae K. and Okubo, J. : Epidemiologic studies of Meniere' disease in Japan. In "Meniere's Disease" ed. by Vosteen K. H. et al pp. 194-198 Georg Thieme Verlag. Thiemo-stratton Inc. Stuttgart. N. Y. 1981.

11) Stahle J. Stahle C. and Arenberg I. K. Indicence of Meniere's disease. Arch Otolaryngol. 104 : 99-102, 1978.

12) 水越鉄理, 猪 初男, 石川和光, 渡辺行雄, 山崎 晴子, 渡辺 勈, 大久保仁: 厚生省特定疾患入二 エール病調査研究班によるメニエール病の疫学調 查と症状調査.耳鼻臨床 70 ：増 $5 ； 1669-1686$ 1977.

13) Morrisson A. W. (ed) : Management of sensorineural deafness chapt. 5: Endolymphatic hydrops pp. 145-174 Butterworths London Boston 1975

14）安田宏一：メニエール病と寒さ.耳鼻 18 : 1116,1972 .

15）安田宏一, 時出 喬, 宮出英雄, 高安㕫次, 香取 早苗, 山崎 勤, 酒井 昇, 山川宗位, 柳内 統 : 札沅，立川，岐阜，福隃におけるメ二エール为庤 発作と父像に関する同侍調查. 耳鼻 18：946$954,1978$.

16) Harrison M. S. and Naftalin L.: Meniere's Disease. Mechanism and management. Thomas Springfield 1968.

17）水越鉄理, 石川和光, 渡辺行雄, 山崎晴子, 五十 嵐淑晴, 黒田京子, 渡辺 勈, 大久保仁: 両側入 ニエール病の疫学臨休的研究. 耳鼻臨床 73 : 増 $2 ; 1010-1022,1980$. 